\title{
Time series of forest land cover change in the Upper Citarum Watershed, West Java Province, Indonesia
}

\author{
Erline Fitridiah Pitaloka ${ }^{1 *}$, Mahawan Karuniasa ${ }^{1}$, and Setyo Sarwanto Moersidik ${ }^{1}$ \\ ${ }^{1}$ School of Environmental Science, Universitas Indonesia, Central Jakarta 10430, Indonesia.
}

\begin{abstract}
The Upper Citarum Watershed experiences exploitation of space and natural resources problems due to urbanization. Development mismatch based on spatial zoning causes the reduced function of protected areas and degradation of natural resource conservation. Forest, as a water catchment area, has a significant role in environmental sustainability. This study combines literature review methods and spatial analysis to determine the time series of forest land cover change between 2009, 2014, and 2019 by analyzing LULCC in the Upper Citarum Watershed. This study indicates that the time series of forest land cover in the Upper Citarum Watershed has undergone a significant change. Forest increased by $4.63 \%$ between 2009 and 2014, and by $32.19 \%$ between 2014 and 2019. Based on the mandate of Law no. 41 of 1999 concerning Forestry, the area of forest that must be maintained is at least $30 \%$ (thirty percent) of the area of watershed and/or islands with a proportional distribution. With the forest area of $23.61 \%$ of the Upper Citarum Watershed, the existing condition has not yet reached the target. So that in the future, collaboration between parties is still needed to achieve forest and watershed sustainability in the Upper Citarum Watershed.
\end{abstract}

\section{Introduction}

Land use and land cover changes (LULCC) pose a significant threat to watershed sustainability and harm many human activities [1]. Changes in forest land use to non-forest, such as agriculture, settlement, industry, plantations, and others, tend to negatively impact [2] because it causes a decrease in water catchment areas [3]. An increase in population can put pressure on the water catchment area. As a water catchment area, the forest has a significant role in the sustainability of water availability and quality [4]. Conversion of the forest into residential areas will eliminate the upstream area's role as water catchment areas and protect the areas under it [5]. Functional shifts in forest vegetation also increase the risk of extinction of water resources, directly impacting the erosion of fertile soil, degraded lands, landslides [6], sedimentation, flooding, and drought [7]. The existence of primary forest in water resource areas will support sustainability because plant populations can absorb and store large amounts of water [8]. The close relationship between forest and

\footnotetext{
* Corresponding author: erline.fitridiah@ui.ac.id
} 
water, and the traditional relationship between agriculture and water, needs to be recognized and protected to ensure sustainable productivity [9].

The Upper Citarum Watershed experiences a fast LULCC, which degrades the watershed conditions and decreases water quality in the Citarum Watershed [10]. Deforestation and urbanization are the most influential factors in changing hydrological processes and sedimentation in the Upper Citarum Watershed [11]. Urbanization is triggered by differences in growth or inequality of facilities from development, especially between rural and urban areas. It took a long time for Bandung to change its settlements' socio-spatial conditions from previously rural areas to then changing into typical metropolitan settlements. These changes were caused by many factors: the booming industry, colonial government politics, and the explosion of urbanization. Development mismatch based on spatial zoning causes the reduced function of protected areas and water resource conservation degradation. This is the cause of the increase in critical land in the Citarum Watershed and impacts the increased run-off and sedimentation in the Citarum River [12]. The hydrological criticality of the watershed is important to understand the process related to the imbalance caused by LULCC [13].

Previous literature has detected LULCC in Upper Citarum Watershed and indicates a significant change in the proportion of different types of LULC in the study area from 1997 to 2014 [10]. Other literature has also predicted LULC in 2029 using the Land Change Modeler (LCM) model and concluded that this change in LULC could increase the intolerable area of erosion [11]. LULC changes play an essential role in the study and analysis of global change scenarios today. The data available on such changes is essential for providing critical input to ecological management and environmental planning for the future [14]. Therefore, this study aims to determine the time series of forest land cover change between 2009, 2014, and 2019 by analyzing LULCC in the Upper Citarum Watershed. This study will provide input on the optimization of forest rehabilitation activities in the Upper Citarum Watershed.

\section{Method}

\subsection{Case study location}

The area of the Upper Citarum Watershed through 5 (five) administrative regions, namely Bandung City, Bandung Regency, West Bandung Regency, Sumedang Regency, and Cimahi City, which consists of 7 sub-watersheds, namely Cimeta, Cikapundung, Citarik, Ciminyak, Ciwidey, Cisangkuy, and Cirasea. Geographically. It is located between $107^{\circ} 22^{\prime} 50.606^{\prime \prime}-107^{\circ} 56^{\prime} 46.297^{\prime \prime}$ East Latitude and 645'40.112"-7º $14^{\prime} 27.018^{\prime \prime}$ South Latitude with the following boundaries:
a. Purwakarta Regency and Subang Regency border north side.
b. The western part of Bandung Regency borders the west side.
c. Eastside is bordered by Sumedang and Garut Regencies.
d. Southside is bordered by Cianjur and Garut Regencies. 


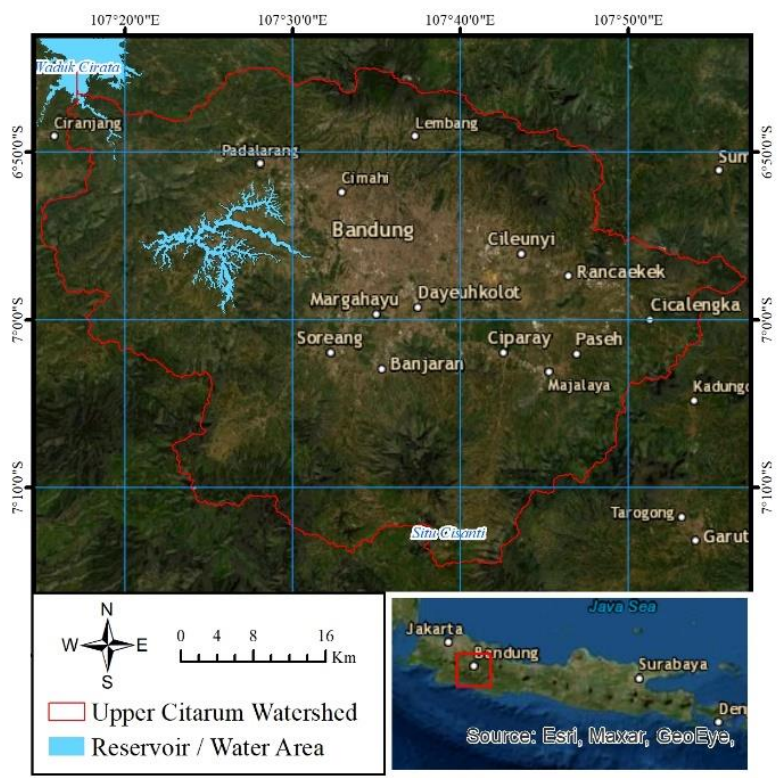

Fig. 1. Upper Citarum Watershed boundary (Source: Author's Analysis, 2020)

\subsection{Data collection and analysis}

This research was conducted with a focus on the Upper Citarum Watershed. The analysis was carried out in a time series by taking a sample year in each multiple of 5 years, namely 2009,2014 , and 2019. The data used is geographic information data on a land-use scale of 1:250,000 at the research location, published by the Ministry of Environment and Forestry of the Republic of Indonesia (KLHK). Meanwhile, the upstream boundary for river flow is obtained from the digital elevation model (DEM) image data processing with 30 meters, published by the Geospatial Information Agency of the Republic of Indonesia (BIG). The background for using and analyzing the data is to get the same perspective as the stakeholders regarding the research area's existing conditions. This method is also taken so that there is a harmony of research results that can be used as an input to stakeholders in realizing sustainable management of the Citarum River Watershed.

Digital Elevation Model (DEM) image data processing is performed using the Basin Spatial Analyst extension in ArcGIS software. While the percentage of data analysis on changes in the land use area at the research location was carried out using three mechanisms. The first analysis mechanism is cropping geospatial information data on land use using geospatial information data on the Upper Citarum watershed boundary. The second mechanism of analysis is to simplify the typology which initially referred to the Indonesian National Standard (SNI) Number 7645: 2010 to be more relevant to the direction of research objectives, in the form of forest, bare land, bush/shrub, plantation, built up, waterbody, agriculture, paddy field, and mining. The third analysis mechanism calculates and compares each land use area at the research location in the years (time series) used as the sample $(2009,2014$, and 2019). In simple terms, the stages of the technical analysis method used in this research can be seen in Figure 2. 


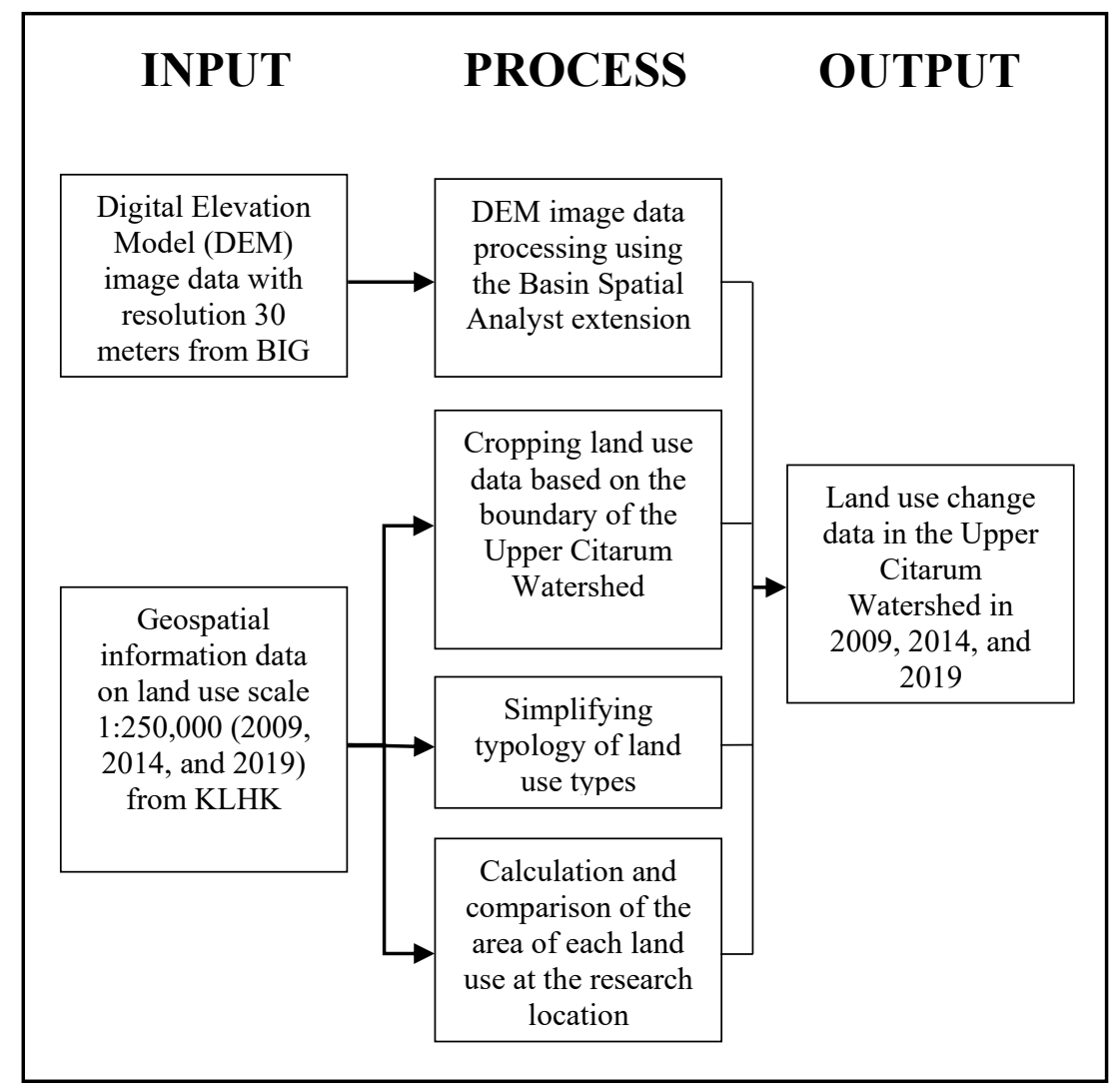

Fig. 2. Flowchart of land-use change analysis method in the Upper Citarum Watershed (Source: Author's Analysis, 2020)

\section{Results and discussion}

In the time series, the Upper Citarum Watershed experienced LULCC, which can be seen in Fig. 3, 4, and 5. The analysis results of changes in each LULC category can be seen in Table 1. Forest area of 44,799 ha in 2009 increased by $4.63 \%$ to 46,875 ha in 2014 . After five years, the forest area became 61,964 ha in 2019. Forest land cover change between 2014-2019 was quite significant, increasing by $32.19 \%$. From 2009 to 2019 , there was an increase in forest area by $38.32 \%$. In 2009 the plantation covered 6,515 ha and increased by $22.71 \%$ to 7,994 ha in 2014 . There was an increase in plantation area by $4.37 \%$ to 8,344 ha in 2019. From 2009 to 2019, there was an increase in plantation area by $28.08 \%$. Agriculture area of 88,027 ha in 2009 experienced a change of $22.51 \%$ in 2014 to an area of 107,839 ha. On the other hand, between 2014 and 2019, the agriculture area decreased by $18.71 \%$ to 87,661 ha. Therefore From 2009 to 2019 , there was a decrease in the agriculture area by $0.41 \%$. Paddy field covered an area of 69,929 ha in 2009 and changed to an area of 51,150 ha in 2014 , indicating a decrease in the area of $26.85 \%$. In 2019 , the paddy field covering 44,991 ha showed that the area decreased by $12.04 \%$ between $2014-2019$. From 2009 to 2019 , there was a decrease in the paddy field area by $35.66 \%$.

In 2009, bush/shrub-covered 1,673 ha and decreased by $85.13 \%$ to 249 ha. Between 2014-2019 there was an increase in area by $150.18 \%$ to 622 ha in 2019. From 2009 to 2019, there was a decrease in the bush/shrub area by $62.81 \%$. The built-up area in 2009 was 
44,216 ha and decreased by $4.77 \%$ to 42,107 ha in 2014. In 2019 the built-up area was 51,092 ha, which shows an increase of $21.34 \%$. From 2009 to 2019, there was an increase in the built-up area by $15.55 \%$. The waterbody area in 2009 was 2,530 ha and increased by $77.33 \%$ to 4,486 ha in 2014. In 2019 it was 4,430 ha, which means that it decreased by $1.24 \%$. Therefore From 2009 to 2019 , there was an increase in the water body area by $75.14 \%$. In 2009, bare land was 4,777 ha and decreased by $64.51 \%$ to 1,696 ha in 2014 . Meanwhile, in 2019 it increased by $91.64 \% \%$ to 3,249 ha. From 2009 to 2019, there was a decrease in the bare land area by $31.98 \%$. The mining area was not found in LULC in 2009, but in 2014 it was 69 ha of the mining area. Meanwhile, in 2019 there was an increase of $59.38 \%$ to 111 ha. Changes in 2009-2014 and 2009-2019 are invaluable because the previous area was zero.

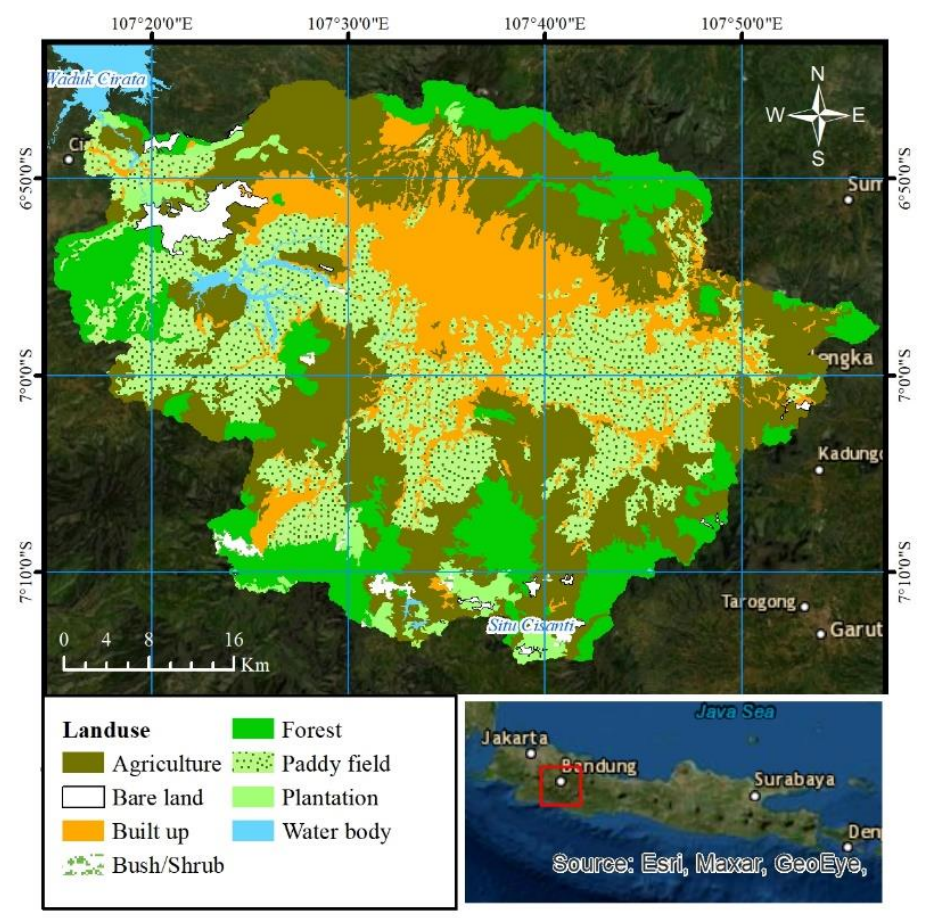

Fig. 3. LULC map of Upper Citarum Watershed (2009) (Source: Author's Analysis, 2020) 


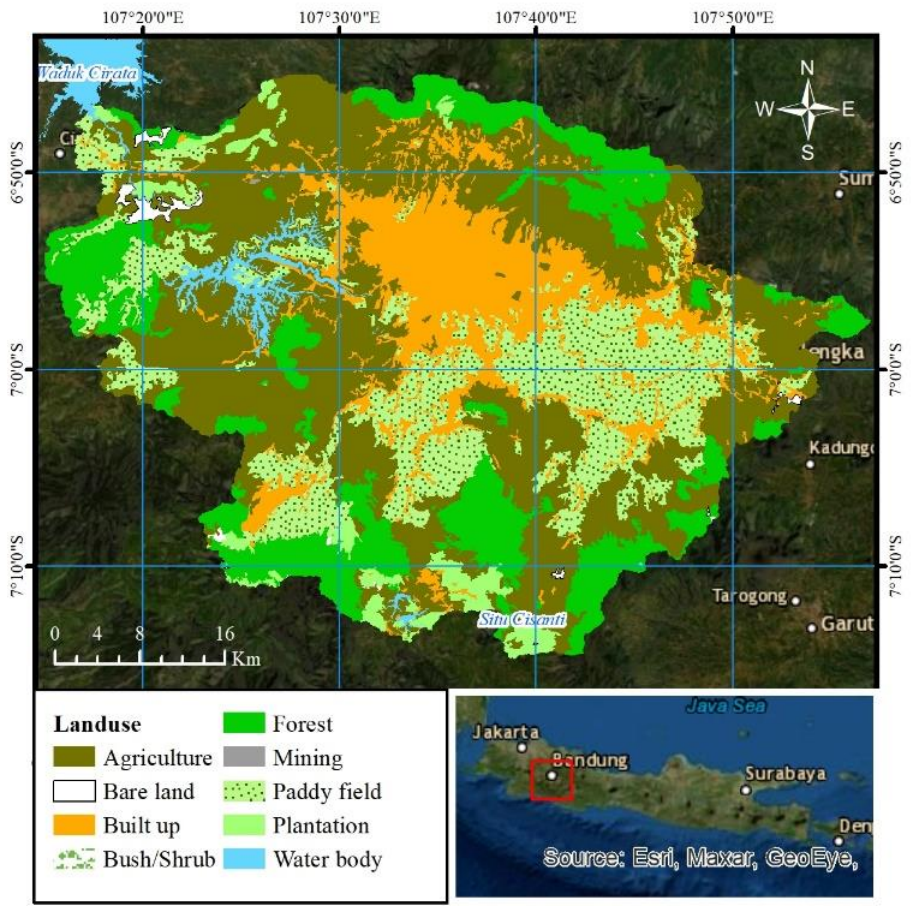

Fig. 4. LULC map of Upper Citarum Watershed (2014) (Source: Author's Analysis, 2020)

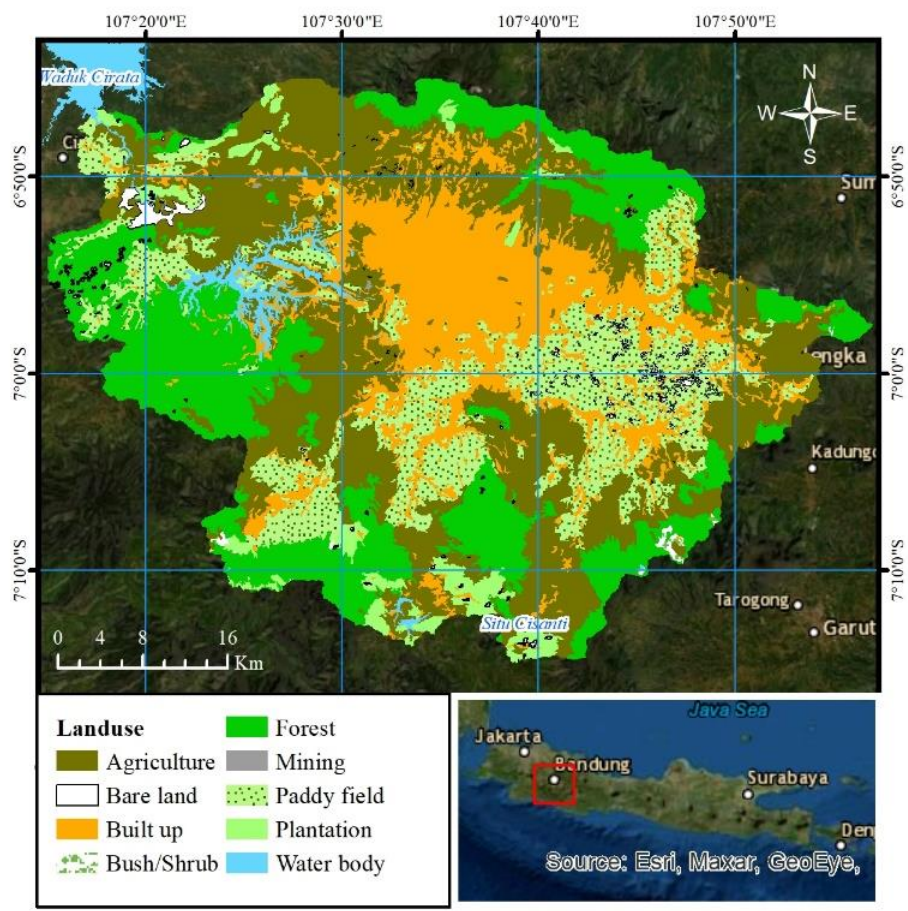

Fig. 5. LULC map of Upper Citarum Watershed (2019) (Source: Author's Analysis, 2020) 
Table 1. LULC area and change of Upper Citarum Watershed (2009, 2014, and 2019)

\begin{tabular}{|l|r|r|r|r|r|r|}
\hline \multirow{2}{*}{$\begin{array}{c}\text { LULC } \\
\text { Category }\end{array}$} & \multicolumn{3}{|c|}{ Area (ha) } & \multicolumn{1}{c|}{ Change (\%) } \\
\cline { 2 - 7 } & \multicolumn{1}{c|}{2014} & \multicolumn{1}{c|}{2019} & $2009-2014$ & \multicolumn{1}{c|}{$2014-2019$} & $2009-2019$ \\
\hline Forest & 44,799 & 46,875 & 61,964 & +4.63 & +32.19 & +38.32 \\
\hline Plantation & 6,515 & 7,994 & 8,344 & +22.71 & +4.37 & +28.08 \\
\hline Agriculture & 88,027 & 107,839 & 87,661 & +22.51 & -18.71 & -0.41 \\
\hline Paddy field & 69,929 & 51,150 & 44,991 & -26.85 & -12.04 & -35.66 \\
\hline Bush/Shrub & 1,673 & 249 & 622 & -85.13 & +150.18 & -62.81 \\
\hline Built up & 44,216 & 42,107 & 51,092 & -4.77 & +21.34 & +15.55 \\
\hline Water body & 2,530 & 4,486 & 4,430 & +77.33 & -1.24 & +75.14 \\
\hline Bare land & 4,777 & 1,696 & 3,249 & -64.51 & +91.64 & -31.98 \\
\hline Mining & 0 & 69 & 111 & - & +59.38 & \\
\hline \multicolumn{1}{|c|}{ TOTAL } & 262,465 & 262,465 & 262,465 & & & \\
\hline
\end{tabular}

Notes: decreased (-), increased (+)

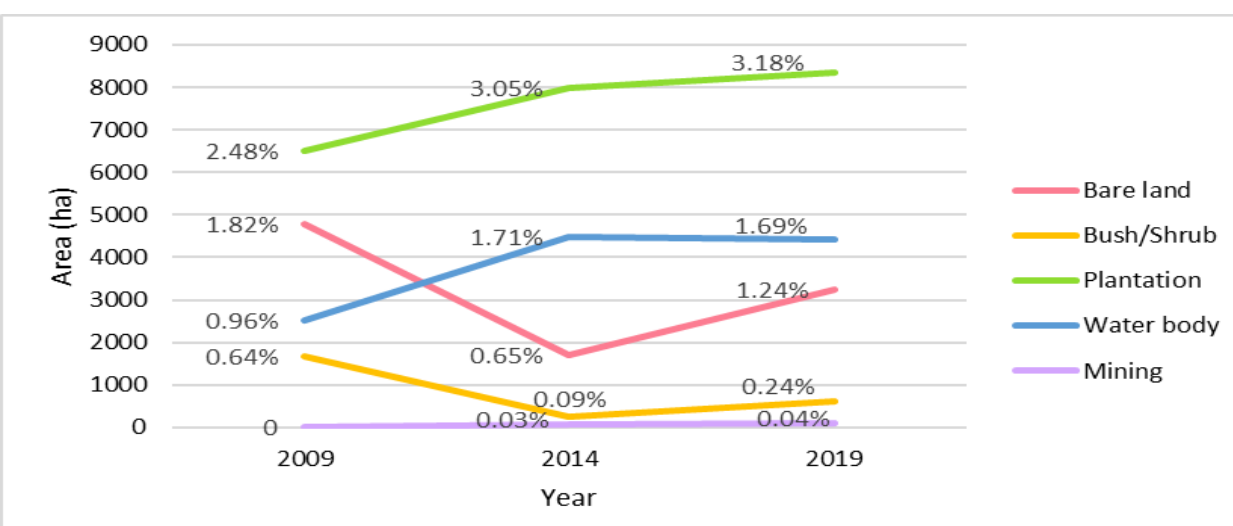

Fig. 6. LULCC of Bare Land, Bush/Shrub, Plantation, Water Body, and Mining in the Upper Citarum Watershed (2009, 2014, and 2019) (Source: Author's Analysis, 2020)

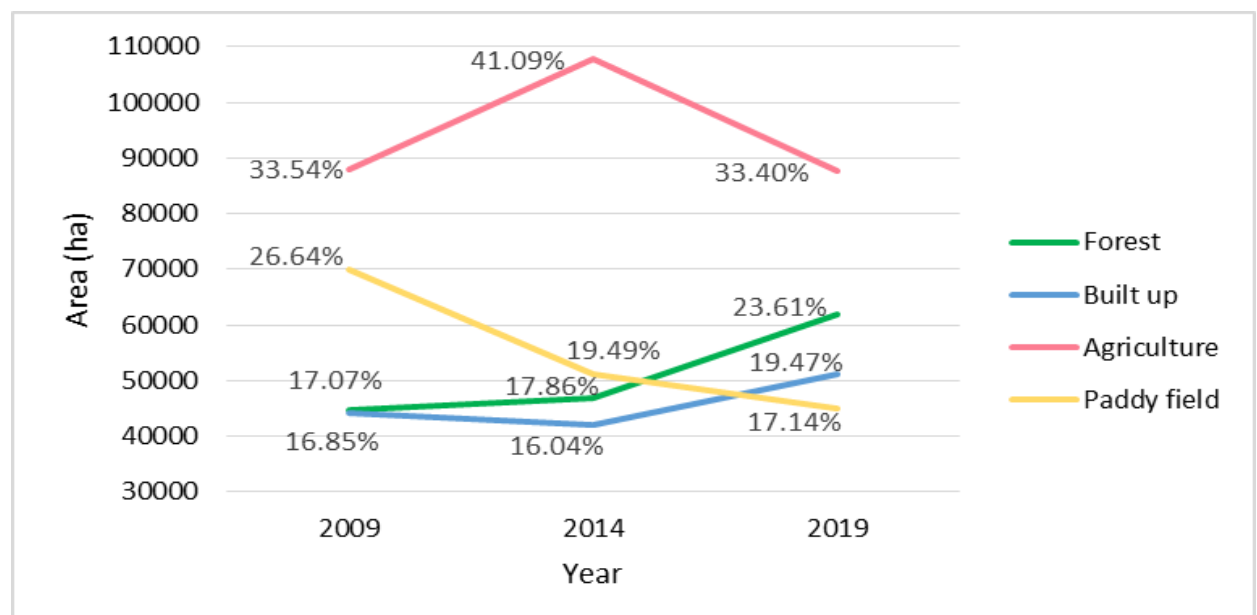

Fig. 7. LULCC of Forest, Built-Up, Agriculture, and Paddy Field in the Upper Citarum Watershed (2009, 2014, and 2019) (Source: Author's Analysis, 2020)

There was a significant LULCC, especially in the LULC forest, agriculture, paddy field, and built-up categories, which dominated land use in the Upper Citarum Watershed. From 
time-series data shows in Fig 6 and 7, it can be seen that agricultural land has always been the most considerable land use. In 2019, the agriculture land was around $33.40 \%$ of the Upper Citarum Watershed area. The time series shows that the area of the paddy field is decreasing. Built-up land decreased between 2009-2014 but increased again between 20142019. The increasing built-up land is evidence of the urbanization phenomenon.

On the other hand, in time series, it can be seen that the forest has continued to experience an additional land area. There was a drastic increase in the forest area between 2014-2019. This shows the success of planting activities in the Upper Citarum Watershed, which support forest and land rehabilitation activities (RHL). RHL is one of the strategic efforts and is a priority policy for forestry development, one of the programs for forest and land rehabilitation activities through the National Movement for Forest and Land Rehabilitation (GN-RHL). GN-RHL is a coordinated forest and land rehabilitation activity that utilizes all government and community capabilities in rehabilitating forests and land in priority watershed areas [15].

In Article 9 paragraph (3) Minister of Forestry Regulation Number 76 of 2008 concerning Forest Rehabilitation and Reclamation, RHL activities are carried out using watershed as a management unit. They are priority watershed areas, one of which is the Citarum Watershed [16]. In the Upper Citarum Watershed, many planting activities are carried out on conservation land in coffee and tea plantation, secondary forest, mixed garden containing industrial plantations, and several gardens planted with Multipurpose Tree Species (MPTS) [17]. The Upper Citarum Watershed is suitable for the concept of agroforestry, which combines tall trees, medium trees, and plantations or agriculture to balance economic and ecosystem benefits [18]. Some examples of crops grown in the Upper Citarum Watershed, both annual and seasonal, are potatoes, ginger, and banana, tomato, guava, jackfruit, mango, and many other plants [19]. Planting activities around the Citarum watershed benefit the community from an economic perspective and increase the area's hydrological cycle [20].

The biggest problem in managing natural resources is overlapping policies between stakeholders/parties. Therefore, all stakeholders that work in the same area must synchronize their policies and programs. The policy must apply sustainable development principles that consider three aspects such as environment, economic, and social. The Bandung regency government has launched a movement called "satapok". Satapok is a movement to involve local communities to plant trees in the Upper Citarum Watershed. Satapok movement also ensures the trees' quality and ensures that the trees can live and produce something. So there will be benefits for the welfare of the people who take care of it. This program is an evaluation of past reforestation activities. Most reforestation programs plant trees without thinking about who will take care of the trees after planting. The funds used in this movement are Corporate Social Responsibility (CSR) funds from various agencies. While the government provides the planting location, and local communities carry out the movement. This is an example of good collaboration between parties, which is proven to increase forest area in The Upper Citarum Watershed.

Based on the mandate of Law no. 41 of 1999 concerning Forestry, the area of forest that must be maintained is at least $30 \%$ (thirty percent) of the area of watershed and/or islands with a proportional distribution. The existing condition in 2019, with the forest area of $23.61 \%$ of the Upper Citarum Watershed, has not yet reached the target set by Law no. 41 of 1999 concerning Forestry. Even though it has not reached the target, there has been a significant change within ten years, wherein 2009, the forest land cover in the Upper Citarum Watershed was only $17.07 \%$. This change shows that many parties have realized the importance of protecting the forest ecosystem in the Upper Citarum Watershed as a catchment area. Sustainable forest management activities must be implemented to protect $23.61 \%$ of the existing forest and increase the forest area to reach $30 \%$ or even more. 


\section{Conclusion}

LULC in the Upper Citarum Watershed continues to experience changes as a result of various human activities. It is necessary to monitor LULC to maintain the stability of the watershed ecosystem. The need for the development of built-up land continues to increase in line with the phenomenon of urbanization, especially in the city of Bandung. The increasing population also as phenomena cannot be denied that it will increase built-up land. From the research results, it can be seen that built-up land is increasing in 2019, with $19.47 \%$ of the total area of Upper Citarum Watershed. Forest land area continues to increase along with the increasing awareness of many parties to protect the forest ecosystem. Based on the research results, it can be concluded that the forest area of around $23.61 \%$ in 2019 is the success of many reforestation activities carried out in the Upper Citarum Watershed. In the future, collaboration between parties is still needed to maintain and increase forest area and achieve watershed sustainability in the Upper Citarum Watershed.

\section{References}

1. G. C. K. Boongaling, D. V Faustino-eslava, F. P. Lansigan, Modeling land use change impacts on hydrology and the use of landscape metrics as tools for watershed management: The case of an ungauged catchment in the Philippines, Land Use Policy 72 (2018) https://doi.org/10.1016/j.landusepol.2017.12.042

2. W. S. Pradafitri, S. S. Moersidik, C. Abdini, East Canal Flood as PDAM water resource DKI Jakarta, E3S Web Conf. 74, 09001 (2018)

https://doi.org/10.1051/e3sconf/20187409001

3. Bursamin, S. P. Utama, M. F. Barchia, Analysis of Sustainability Management of the Bengkulu Watershed Based On the Community, J. Nat. Resour. Manag. Environ. Res.7, 2 (2018)

4. D. A. Armadi, A. Hidayat, S. M. H. Simanjuntak, Analysis of Sustainable Clean Water Management in Bogor City (Case Study: PDAM Tirta Pakuan), J. Agric. Resour. Environ. Econ. 2 (2019) https://doi.org/10.29244/jaree.v2i1.25928

5. G. Salim, I. W. S. Dharmawan, B. H. Narendra, The Effect of Changes in Forest Land Cover Area on the Hydrological Characteristics of the Upper Citarum Watershed, J. Environ. Sci.17, 2 (2019) https://doi.org/10.14710/jil.17.2.333-340

6. S. Robo, H. Pawitan, S. D. Tarigan, B. D. Dasanto, Projected Change in Land Use and Impact on the Hydrological Response of the Upper Ciliwung Watershed, J. Eng. Technol. 3, 2 (2018) https://doi.org/10.31544/jtera.v3.i2.2018.157-166

7. Divinsky, N. Becker, P. Bar, Ecosystem service tradeoff between grazing intensity and other services - A case study in Karei-Deshe experimental cattle range in northern Israel, Ecosyst. Serv. 24 (2017) https://doi.org/10.1016/j.ecoser.2017.01.002

8. M. Karuniasa, P. A. Pambudi, Transition of Primary Forest To Secondary Forest and the Impact for Water Resources Conservation, J. Environ. Sci. Sustain. Dev. 2, 1 (2019) https://doi.org/10.7454/jessd.v2i1.34

9. M. Kumari, J. Singh, Water Conservation: Strategies and Solutions, Int. J. Adv. Res. Rev.1, 4 (2016) www.ijarr.in

10. M. Agaton, Y. Setiawan, H. Effendi, Land Use/Land Cover Change Detection in An Urban Watershed : A Case Study of Upper Citarum Watershed, West Java Province, Indonesia, Elsevier Procedia Environ. Sci. 33 (2016) https://doi.org/10.1016/j.proenv.2016.03.120 
11. S. Y. Siswanto, F. Francés, How land use / land cover changes can affect water, flooding and sedimentation in a tropical watershed : a case study using distributed modeling in the Upper Citarum watershed, Indonesia, Environ. Earth Sci.78, 550 (2019) https://doi.org/10.1007/s12665-019-8561-0

12. RAM-IP, Rencana Aksi Multipihak Implementasi Pekerjaan (Multistakeholder Action Plan for Work Implementation), Bandung, Indonesia, (2016)

13. H. Nurcahyo, I. Soekarno, I. K. Hadihardaja, A. Rosyidie, Development Flow Duration Curve for Criticality Assesment of River Basin Applied at The Upper Citarum River Basin, Indonesia, Int. J. GEOMATE 13, 39 (2017) https://doi.org/10.21660/2017.39.98214

14. Z. Hassan et al., Dynamics of land use and land cover change (LULCC) using geospatial techniques: a case study of Islamabad Pakistan, Springerplus 5, 581 (2016) https://doi.org/10.1186/s40064-016-2414-z

15. Nirawati, B. Nurkin, B. Putranto, Evaluation of the Success of Plant Growth in Forest and Land Rehabilitation Activities (GNRHL) in Bantimurung Bulusaraung National Park (Study of GNRHL Activities 2003-2007), J. Sci. Technol.13, 2 (2013)

16. R. M. Rachman, A. Satria, G. Suprayitno, Designing a Strategy to Strengthen the Implementation of Land and Forest Rehabilitation Policies Case Study in Bangunjaya Village, Cigudeg District, Bogor Regency, West Java, J. Bus. Manag. Appl. 2, no. 2, pp. 196-206, 2016 https://doi.org/10.17358/jabm.2.2.196

17. F. Yulianto, Suwarsono, S. Sulma, Improving the accuracy and reliability of land use/land cover simulation by the integration of Markov cellular automata and landform-based models - a case study in the upstream Citarum watershed, West Java, Indonesia, J. Degrad. Min. Lands Manag. 6, 2 (2019) https://doi.org/10.15243/jdmlm.2019.062.1675

18. M. S. Idris, A. S. C. Permadi, A. I. Kamil, B. R. Wananda, A. R. Taufani, Citarum Harum Project: A Restoration Model of Citarum River Basin, Indonesia. J. Dev. Plan. 3, 3 (2019) https://doi.org/10.36574/jpp.v3i3.85

19. J. Prihatini, J. Iskandar, R. Partasasmita, D. Nurjaman, The impacts of traditional homegarden conversion into the commercial one: A case study in sukapura village of the upstream citarum watershed, west java, indonesia, Biodiversitas 19, 5 (2018) https://doi.org/10.13057/biodiv/d190545

20. F. Yulianto, T. Maulana, M. R. Khomarudin, Analysis of the dynamics of land use change and its prediction based on the integration of remotely sensed data and CAMarkov model, in the upstream Citarum Watershed, West Java, Indonesia, Int. J. Digit. Earth (2018) https://doi.org/10.1080/17538947.2018.1497098 